Слободан Бјелица

Универзитет у Новом Саду

Филозофски факултет

Одсек за историју

sbjelica@eunet.rs
Оригиналан научни рад

примљено: 14. април 2014

прихваћено: 1. октобар 2014

\title{
ПРИЛОГ ПРОУЧАВАњУ ИСТОРИЈЕ МАТИЦЕ СРПСКЕ И ФИЛОЗОФСКОГ ФАКУЛТЕТА У НОВОМ САДУ
}

Сажетак: Две знамените новосадске установе - Матица српска и Филозофски факултет - ове године обележавају значајне јубилеје. То је прилика да се научна јавност упозна са досада необјављеним подацима из записника војвођанског Покрајинског комитета Савеза комуниста. Ова документација, која се чува у Архиву Војводине, не само да пружа драгоцене податке о раду поменутих институција у време социјалистичке Југославије него и сведочи о пажњи коју је ондашња власт посвећивала догађајима „у и око“ Матице српске и Филозофског факултета. Хронолошки оквир рада обухвата период од првих година након краја Другог светског рата, па све до времена поткрај шездесетих година. Студентске демонстрације, МАСПОК, пад „либерала“ и остали изазови са којима су се партијски и државни органи суочили у наредним годинама Матицу и Филозофски факултет су ставили под још јачу политичку присмотру и притисак - због чега то доба остављамо за неко будуће истраживање. факултет.

Кључне речи: Матица српска, Нови Сад, Покрајински комитет, Филозофски

На дневном реду Покрајинског комитета Комунистичке партије Србије за Војводину разматран је, средином новембра 1947. године, рад Матице српске и културних савеза Словака, Русина и Румуна. Поред чланова ПК, присутни су били и Живан Милисавац из Матице српске, Јурај Спевак из Матице словачке, Аурел Труфу из Културног савеза Румуна и „друг Варга“ из Руске Матке. На самом почетку Живан Милисавац је укратко изложио историју Матице српске, као и тренутни положај Матице у друштву. Подсетио је да је после ослобођења управо ПК „одредио оквире рада Матице српске и поставио да Матицу српску треба оживети због њених традиција, око ње окупити људе који би могли да је развијају на пољу ширења културе и просвете. Оснивајући месне организације Матице српске кроз њих вршити читав културно-просветни рад на селу у српским местима, као и у граду. Наставити са издавањем Летописа Матице српске, који треба да буде књижевни лист и око њега окупљати и уздизати младе војвођанске књижевнике. Развијати институције Матице српске: библиотеку, галерију слика и музеј. Развити издавачку 
делатност Матице српске издајући војвођанске писце“. ${ }^{1}$

Наглашавајући да је, након што су одређени задаци Матице српске и задат оквир њеног рада, „уз помоћ ПК“ уписано у Матицу око 7.000 чланова и да су израђена и одобрена њена правила, Милисавац је констатовао да рад Матице српске „није много напредовао у периоду од 1945. до 1947. године“. Стога је Агитпроп ПК размотрио деловање Матице и донео предлог да се она „поново оживи, да јој се да садржина рада и помогне на организационом и финансијском сређивању“. Након израде предлога, Митра Митровић је позвала на разговор Милисавца, као секретара Матице српске, на коме му је изнела своје гледиште да су се матичари „у својим плановима залетели“ и хтели да створе од Матице српске централну културну установу Срба у Војводини. По мишљењу М. Митровић, то је било беспотребно будући да су у то време постојале друге организације са истим циљевима и задацима, а Матица је требало да буде „културна организација у граду Новом Саду са врло уским бројем чланства, које би у њу улазило на основу заслуга у раду на културном пољу или на основу тога што би као образовани људи на томе пољу могли нешто допринети“.

Након читања извештаја које су поднели секретари културних савеза националних мањина и дискусије која је уследила, донет је закључак да „Матица српска треба да остане репрезентативна установа у Новом Саду, са уским бројем чланства, које ће у центру развијати свој рад у својим секцијама и преко слања људи на терен остваривати своје задатке. Библиотеку и галерију треба постепено претворити у државне институције“. Предвиђене су пуне две године за завршетак процеса преображаја Матице из „културно-масовне организације“ у „културнонаучну установу“. 2

На дневном реду Секретаријата ПК СКС за Војводину септембра 1953. године било је најављено отварања факултета у Новом Саду. Реферат је поднела Зора Крџалић, која је издвојила два основна разлога за отварање факултета у покрајинском центру: потреба за стручним кадром (агрономи, професори, лекари, правници), као и даљи културни развитак града. У дискусији је оцењено да услови за отварање факултета постоје али да ће најтеже бити решити кадровска питања. Донет је закључак да се затражи од Извршног већа НР Србије отварање четири факултета, „и то сукцесивно“: прво Пољопривредног и Филозофског, а потом и Медицинског и Правног. Као следећи корак предвиђено је расписивање конкурса за будуће професоре, који би, у периоду од свог избора па до уписа студената, стицали искуства на другим факултетима. Посебно је наглашено да се састави једна група стручњака која би предложила „место где би се у перспективи градили факултети, институти и друге потребне институције у вези са отварањем факултета““3

\footnotetext{
* Текст је настао као фазни резултат рада на пројекту Војвођански простор у контексту европске историје (број 177002) Министарства просвете, науке и технолошког развоја Републике Србије.

${ }^{1}$ Архив Војводине (даље: АВ), Фонд 334, Записник са седнице ПК КПС за Војводину од 14. 11. 1947.

${ }^{2}$ Ипак, у Годишњем извештају ПК за 1949. годину констатовано је да партијски утицај на рад Матице српске „иако у њој ради приличан број комуниста - је недовољан, и то стање би требало хитно решити“. Ненад Дошлић, Матииа српска 1941-1951, Нови Сад 2011, 206.

${ }^{3} \mathrm{AB}$, Фонд 334, Записник са седнице Секретаријата ПК СКС за Војводину од 21. 9. 1953.
} 
Рад Матице српске поново је анализиран на пленарној седници Покрајинског комитета априла 1954. године, у оквиру шире дискусије о културнопросветној политици Партије у Војводини. У реферату насловљеном „О неким идеолошким проблемима и издавачкој делатности“, Нандор Фаркаш је приличан простор посветио раду Матице српске. Анализирао је петогодишњи учинак деловања Матичиног Научног одељења, односно његових секција за историју, етнологију, ликовну уметност, природне науке и за библиографију. Подсетио је да су Научном одељењу „додељени задаци“ да створи услове за научни рад у Матици и организује тај рад, „нарочито на проучавању Војводине“, да води евиденцију о научним радницима Војводине, да даје предлоге и спрема научне публикације за издавање, да се стара о научном подмлатку и да остварује сарадњу са другим сличним установама у Војводини. Оценио је да је Научно одељење, „са мање или више успеха“, испунило своје задатке „и то уз релативно врло скромна средства“. Поменуо је да је око тог одељења окупљено педесетак најспособнијих војвођанских научника, свих националности, који су припремили и објавили у Зборнику и у посебним монографијама своје радове, иако су они, према његовом суду, били кориснији „као грађа него као научни рад“. 4

Као основни недостатак у раду Научног одељења Фаркаш је навео неуспех у стварању научног подмлатка: „Одељење не уздиже млад кадар“. Тај посао је стога требало препустити будућем Филозофском факултету. Поновио је своју оцену да се запостављају културне и историјске вредности мањина у Војводини, односно заједнички живот свих националности у Покрајини. Критиковао је Матичино Научно одељења и што стихијски ради, без ,једног одређеног чврстог курса и оријентације“. У том смислу, навео је да се у зборницима и сепаратима објављују радови који „нису нам сада најпотребнији“, и истакао као примере рад Н. Радојчића „Душанов законик“ и рад М. Филиповића „Трачки коњаник“. Приметио је и да су у раду „Народне ношње у Војводини“ обухваћене само српске народне ношње, а као посебан проблем критиковао је високе цене Матичиних издања које онемогућавају популаризацију науке. „Књиге леже у магацину“, опоменуо је Фаркаш.

У реферату је посебно анализиран рад војвођанских историчара. Иако је Секција за историју Матице српске похваљена за своје ангажовање у правцу сакупљања грађе за монографију војвођанских места, Фаркаш је упутио и извесне критике. Пре свега, приметио је појаву да се „мали број научних радника цепа на више страна“ - поред Секције за историју при Научном одељењу Матице српске постојала је иста таква секција, са истим члановима, при Војвођанском музеју, као и Историјско одељење у оквиру ПК. Као највећи пропуст навео је то што „засада нема изучавања суштинских питања за нашу Покрајину: историје, а нарочито историје радничког покрета, даље, историје, заједничког живота свих националности које живе на овом подручју. Приватна иницијатива Матице српске је позитивна али садашње потребе су већ прерасле њен оквир, а један део њених научних снага и по социјалном саставу и по политичком схватању далек је нашој стварности а на пример историја револуционарне борбе војвођанског пролетеријата која је препуна

${ }^{4} \mathrm{AB}$, Фонд 334, Записник са седнице ПК СКС за Војводину од 16. 4. 1954. 
примерима стварног пролетерског братства - њих не интересује“. Стварање „новог оквира““ за изучавање историје требало је поверити будућем Филозофском факултету у Новом Саду.

О проблему стварања „нове интелигенције“ говорили су и учесници у дискусији која је уследила. Сава Мали је приметио да у научним заводима у Војводини, не само у историјско-друштвеним него и у пољопривредним и осталим, „доминирају ти стари, формирани кадрови у тој области. Ми идемо врло споро са стварањем нових научних кадрова“. Тадашњи систем стипендирања, који се углавном базирао на социјалној компоненти, по оцени Малог, довео је до тога да су нови научни радници долазили „из редова ситне буржоазије, са села из кулачких породица. Сем тога, као што сам рекао, прошли су фактички кроз образовање у коме има много старог, тако да и тамо није било довољно борбе за стварање марксистичког погледа на свет. Зато видимо да и међу тим млађим кадровима има добар број људи који се у научном погледу много не разликују од оних старих“. Мали је предложио да партијски одбори и раднички савети форсирају младе „из сиромашних сељачких и радничких породица са одређеном намером да те људе стипендирају да би за пар година имали сасвим други класни састав тих интелектуалаца“. У сличном тону је говорио и Стеван Дороњски, који је кривицу за незадовољавајуће карактеристике младих интелектуалаца пребацио на школе из којих долазе: „Значи, нешто у настави на универзитету није у реду, јер ми производимо такве младе интелектуалце који у нашим условима нису у стању да дају оно што је друштвеном систему и радничкој класи потребно“.

Два месеца касније, у склопу расправе о издаваштву, на седници Председништва Социјалистичког савеза, војвођански функционери су се поново дотакли Матице српске. У свом реферату Шоти Пал је приметио да код Матице српске „има неки ђаво. Њено издавачко предузеће је и самостално и није самостално. И имају једно књиговодство и немају једно књиговодство. По нашем мишљењу требало би без даљега да издавачко предузеће буде Кинеским зидом одвојено од Матице српске. Не могу да улазим шта су штампали и како су штампали. Што се тиче регреса, нешто су из Србије добили за Петровића, добили су 200.000 за Змајеву прославу итд. И ту се исто понавља проблем хонорара. Унутар Матице српске они раде нека научна дела и Матица сама даје хонорар за дела издавана од издавачког предузећа. Тако је Младен Лесковац поред плате од 250.000 годишње, примио од Матице српске за неке радове 380.000 , а у издавачком предузећу 180.000. Све у свему преко 600.000 од Матице српске на име плате и на име хонорара плус од издавачке делатности посебно. Или Жива Бошков 150.000 од Матице српске плус 145.000 од издавачке делатности.“ На крају опширне анализе Матичиног издавачког рада, референт је подсетио да Матица српска прима дотацију за задатке одређене њеним Статутом - организовање и помагање научног проучавања Војводине у свим гранама културног живота народа који у њој живе. „То је у Статуту, али ја мислим да се то још никако није постигло“, закључио је Шоти. ${ }^{5}$

На једној од многобројних седница Секретаријата ПК која је била посвећена

${ }_{5}^{5}$ АВ, Фонд 334, Записник са састанка Председништва ССРН за Војводину од 18. 6. 1954. 
питању националних мањина у Војводини, оној одржаној маја 1956. године, Јожеф Нађ је говорио о неким просветним проблемима најбројније мањине - мађарске. За чињеницу да мађарска деца врло слабо говоре српски Нађ је окривио учитељску школу у Суботици, која „не даје нам учитеље који говоре српски“. Као други, ништа мање важан проблем навео је питање програма историје за мањинске школе, због чијих недостатака је, по Нађовим речима, долазило „до разних тенденција изолационистичког и националистичког карактера код националних мањина у круговима просветних радника“. Навео је примере неодговарајућег предавања историје српско-мађарских односа у основним школама, које је код мађарске деце стварало комплексе „ниже вредности“. Као евентуални корак у правцу поправљања недостатака које је навео, Нађ је позвао да се поново размисли о отварању мађарске катедре на Филозофском факултету у Новом Саду, која у том тренутку није постојала „зато што нема наставника“. А присутни изасланик ЦК СКС Слободан Пенезић је предложио много једноставније решење: „Треба укинути учење историје. Историја никад ништа не научи. Американци не уче историју, из историје уче само свој Устав.“6

Нађ је у наставку упозорио да су код свих мањина у Војводини присутне тежње ка националном изолационизму, које „врло често имају корена у спонтано насталом или јасно задржаваном изразито српском карактеру наших највиших културних институција и покрајинског значаја. Оваква стремљења се рађају као антитеза и противстав - према - на пример Матици српској, која није само по називу, него и по садржини рада српска, а има тежњу и у свим формама се развијала као војвођанска општекултурна установа. Слична ситуација је била и са тенденцијом стварања Галерије Матице српске“. Нађову тезу је током дискусије подржао Душан Секић, који је позвао „да се полако иде на уклањање свих облика и форми које раздвајају људе по националним, историјским наслеђеним и необјективним чиниоцима које ми не можемо пренебрегнути, али који ће као што су настали тако и проћи, значи да ми као свесна сила морамо да потпомажемо тај процес. То значи конкретно да би ми требало да уклонимо све што није нужно (неке ствари као што је језик, писмо и тако даље разуме се да не можемо) али све оно друго што није нужно, ја мислим да можемо и да треба да идемо на то. Говорим за школство и ту мислим да морамо да извршимо реформу. Тако исто морамо извршити реформу у свим институцијама. Јер ми на пример имамо Српско лекарско друштво, Матицу српску, па српско ово или оно, српску улицу и тако даље. А са друге стране тога исто има и код националних мањина“.

Годину дана касније, у расправи о истој теми - проблемима националних мањина у Војводини, Ласло Рехак је констатовао да је „новосадска катедра српскохрватског језика и југословенске књижевности на Факултету у Новом Саду што се тиче језичке групе на приличној научној висини и има свој углед у земљи. Имамо опет Српску академију наука у Београду. Што се тиче њеног нивоа у области српскохрватског језика, она ужива општи углед у научном свету, али за 12 година социјализма на скупштини ове установе ове године - не знам да ли је то била и

${ }^{6}$ АВ, Фонд 334, Записник са седнице Секретаријата ПК СКС за Војводину од 17. 5. 1956. 
дванаеста скупштина после ослобођења - имамо ситуацију да не именујући директно али циљајући на новосадски факултет све указује на то да има неких факултета и факултетских савета који деградирају старословенски језик и такорећи бришу га из наставе. Наш факултетски савет није негирао старословенски језик, али га је мислим поставио на његово право место и по мом мишљењу свакако је то боље поставио него београдски факултет. Ипак, Српска академија наука врти се на својој годишњој скупштини око тога питања а није се сетила других много животнијих проблема“" 7

На дневном реду Секретаријата ПК СКС за Војводину су крајем октобра 1957. године били „Неки проблеми у вези са Матицом српском“. У реферату посвећеном овој, како је написано, једној „од најзначајнијих културних тековина наше прошлости“ која „чини врло крупан и драгоцени део културног наслеђа које је наше социјалистичко друштво преузело из прошлости“, као основна заслуга Матице у прошлости наведено је да је она „као световна, нецрквена установа, врло много допринела очувању националне свести Срба па и других словенских народа у Војводини, а још више, што је нарочито много учинила на пољу стварања и развијања српске интелигенције и српске књижевности“. Поредећи Матичину делатност из времена до 1918. године са периодом између два светска рата, писац реферата је закључио да је за време Хабзбуршке монархије Матица српска, захваљујући својим фондовима, „развијала многоструку делатност, почевши од издавања Летописа и књига до стипендирања српских студената и помагања сиротих удовица и незбринуте деце“. После Првог светског рата, како се наводи, „за Матицу је настао период тражења и лутања“. Како је њену некадашњу улогу преузела држава, Матица се „све више сводила на просветну установу Војводине, вршећи своје просветне функције преко Библиотеке, Музеја, издавачке делатности (која није била већег значаја) и нарочито, преко свога Летописа“. Но будући да је Матица српска још увек баштинила велик углед, „у њој и око ње“ су се у време Краљевине Југославије водиле борбе „свих грађанских политичких партија и група у Војводини од крајње реакционарних, националистичких и шовинистичких до либералнодемократских“, а неколико година пред Други светски рат „одређени утицај и делатност у Матици и на Матицу, извршиле су напредне снаге нашег радничког покрета и КПЈ (Удружена опозиција и Омладински покрет)“. ${ }^{8}$

У наставку је писац реферата подсећао да је у социјалистичку Југославију Матица српска „заједно са драгоценим културним богатством које носи у себи и са собом, донела и баласт своје националне ограничености, ситно-буржоаску идеологију и национално-романтичарске традиције знатног дела својих сарадника и чланова, као и друге сличне установе и организације наслеђене од грађанског друштва. Због тога је Матица требала да послужи, нарочито непосредно после рата, као уточиште и упориште неких великосрпских шовинистичких и антисоцијалистичких елемената“. За опстанак Матице након аграрне реформе заслуга је приписана „активности комуниста и других позитивних социјалистичких

\footnotetext{
${ }^{7}$ АВ, Фонд 334, Записник са седнице ПК СКС за Војводину од 18. 5. 1957.

${ }^{8} \mathrm{AB}$, Фонд 334, Записник са седнице Секретаријата ПК СКС за Војводину од 30. 10. 1957.
} 
снага у њој и ван ње“. Потом се описује свестрана делатност Матице „какве никада у њеној историји није било“, која је била могућа зато што је „друштво преузело на себе финансирање њених институција, Библиотека и Галерија слика, а затим и осталих њених подухвата“. Детаљно су размотрени „место, улога и друштвена функција“ Летописа, издавачке делатности, Књижевног одељења, Библиотеке, Галерије и Научног одељења. За рад овог последњег је оцењено да је знатно допринео „развијању научне делатности у Војводини и извршило онај неопходни, организациони и припремни посао, који омогућује да се пређе бар у неким гранама ускоро на организован, систематски, институтски научни рад“. Ипак, замерено је да се рад Научног одељења ,још увек одвија на дилетантској основи, а у области друштвених наука осећају се још увек јаки утицаји старих, буржоаскоидеалистичких схватања. Нарочити недостатак ових кадрова осећа се у редовима националних мањина“.

У реферату се наводи и да је Матица српска првих година након ослобођења „неко време преживљавала период тражења места у новом социјалистичком друштву“. Покушај оснивања месних одбора, са задатком ширења и пропагирања књига, довео је до тога да су они „постали привлачно језгро за све националистички и шовинистички оријентисане елементе“. Даље се наводи да у раду Матице има још недостатака „како организационе тако и идеолошке природе“. Организационе форме, наслеђене из времена у коме у Новом Саду и Војводини „није било никаквих организованих облика културно-научног рада“, биле су зреле за реформисање и усклађивање са новоствореним институцијама. Упозоравајући да у раду Матице има ,још увек идеолошке оптерећености наслеђене из прошлости, националне ограничености и национално-романтичарских схватања“, писац реферата је ипак закључио да све југословенске академије, универзитети и остале сродне установе „пате од исте болести“. На крају је изражено очекивање да ће се такво стање изменити „када наше социјалистичко друштво буде одгајило себи нове научне и просветне кадрове који ће заменити старе“.

У допуни уз реферат о Матици српској, под насловом „Матица и њена улога у социјалистичкој Југославији“ посебно је подвучено да Матица „може да игра баш због те своје специфичности - врло позитивну улогу и у југословенским размерама, као што се показало приликом акција око језичко-књижевних проблема“. У дискусији која је уследила је, међутим, упозорено како „треба у Матици српској (а у првом реду међу комунистима у њој) рашчистити да Матица српска не може постати у данашњим условима регулатор односа између Срба и Хрвата јер то решавају само одређени друштвено-економски процеси, нити она сме бити привлачна снага за Србе ван Војводине, пошто би се за њу такву могли везивати само људи са буржоаско-националистичким схватањима. Да би Матица српска могла бранити идеју југословенства (која је заснована на нашом друштвеном систему и националној равноправности) мора сама бити постављена на друштвено националне основе овога терена и да делује на интернационалистичким принципима“. Наведене „слабости“ стављене су на душу члановима Партије, који нису показали „довољно активности у идеолошкој борби са одређеним схватањима у Матици српској и око ње (као што је традиционализам, културно наслеђе и друго)“. 
На крају је Секретаријат ПК усвојио следеће закључке о Матици српској:

1. „Да су провокаторски гласови о укидању Матице српске и да на то нико не помишља.

2. Функцију Матице српске поставити тако да се саобрази друштвеноекономским условима код нас и нашој културној политици. Да јој се одреди таква функција како би могла да игра прогресивну улогу (постепено је ограничити на књижно одељење са Летописом и издавачком делатношћу). У заједничкој дискусији са комунистима из Матице српске одредити програм појединих Матичиних институција.

3. Идеолошке проблеме у вези са Матицом српском, као и концепцију о Матици српској расправити у идеолошкој комисији, организујући дискусије у првом реду са комунистима из Матице српске, како би се испитала њихова мишљења и ставови.

4. Идеолошка комисија да изанализира Зборник са комунистима који на његовом уређивању раде.

5. Научни рад пренети на постојеће научне институције зависно од карактера те установе, а у Матици српској задржати само оне научне гране за које за сада нема могућности да се развијају ван ње. Регулисати то и политиком буџетирања.

6. Издискутовати карактер Библиотеке (општенародна, универзитетска или друго) и дати конкретне предлоге у вези са њеном даљном перспективом.

7. Дати конкретан предлог о Галерији (њеном статуту, карактеру и даљој перспективи), имајући у виду потребу да Галерија буде самостална научна институција, која је већ прешла оквире Матице српске.

8. Буџетском политиком каналисати делатности у Матици српској. У идеолошкој комисији и Савету за културу АП Војводине сачинити конкретан предлог, до буџетске дебате, о потребним средствима за нормалан рад и даљи развитак свих установа Матице српске. Сва буџетска средства давати Матици српској наменски.

9. Сва та питања расправити са комунистима из управног одбора Матице српске, а потребне одлуке донети у Савету за културу АП Војводине“.

На пленарној седници ПК одржаној маја 1958. године на дневном реду су била „идеолошка кретања“. У опширном реферату Јошке Нађа, између осталог, поменуто је стање на Пољопривредном и Филозофском факултету: „Настава на овим факултетима, оптерећена најразличитијим врстама идеализма, а делимично и мистицизмом, национализмом и другим антимарксистичким предрасудама и заблудама - отвара читав низ проблема, на чијем се решењу морају ангажовати не само комунисти - наставници, него и комунисти студенти и чланови факултетских савета“.9 А на проширеној седници Секретаријата ПК, одржаној јуна 1961. године, говорило се између осталог и о идеолошкој активности на факултетима и вишим

\footnotetext{
${ }^{9} \mathrm{AB}$, Фонд 334, Записник са седнице ПК СКС за Војводину од 24. 5. 1958.
} 
школама. У материјалу припремљеном за седницу наводи се да у извођењу наставе „директног идеолошког застрањивања нема једино у области егзактних дисциплина. У области друштвених наука пренаглашено се осећају историцизам и позитивизам. Ни наставници-комунисти, и поред убеђења, нису увек у стању да марксистички интерпретирају наставно градиво - јер у њима живи оно из старе школе. Ослобађајући се совјетских шаблона, социологизације, нарочито у области литературе, неки напуштају марксистичку интерпретацију и одлазе у импресионизам, па и у идеализам. Тако се књижевност изучава само као нека чиста уметност, а не и као идеологија, па се, по правилу, иде само на естетску анализу дела, што је нарочито карактеристично за групе енглеског и немачког језика (Филозофски факултет)“.

Како је током дискусије приметио Јожеф Нађ, у материјалу за седницу је констатовано да је, у погледу кадрова, најслабија тачка област друштвених наука, „нарочито за изучавање савремених проблема друштвеног развоја, кадрова за психологију, педагогију, филозофију и нову историју“. Предложио је да се на том плану предузму систематске мере како би се превазишла ситуација да „управо на Филозофском факултету тај наставнички кадар је и најслабији по идеолошкој физиономији, убеђености“, и то од стварања факултета. Оценио је да Филозофски факултет касни са реформом програма, односно: „сам Филозофски факултет врло мало и скоро никако се не бави проблемом школске реформе и дискусијама о школској реформи, а и ако се воде ове дискусије на Филозофском факултету, оне су врло непотпуне и даје се одређени одмер према тим дискусијама и према проблемима школске реформе“. Као једну позитивну страну истакао је рад катедре за мађарски језик и књижевност. По ко зна који пут истичући да је за војвођанске комунисте неопходно да стварају „сопствену интелигенцију која ће ипак бити друкчија него стара интелигенција по много чему“, Стеван Дороњски је упозорио да „ако нам нису сређене катедре на Филозофском факултету онда ћемо морати ићи на то да уче у високим политичким школама филозофију... на факултету мора да се роди филозоф марксиста, економист марксиста и тако даље, а не да после иде на доучавање“.

Слично је размишљао и Ђура Јовановић, који је препоручио ,једно пуније и систематизованије изучавање марксизма као теорије“, упитавши се „да ли ми треба и морамо да стварамо будуће генерације историчара да они буду овако, да познају историју ради историје и да буду историчари или треба да стварамо нове конструктивне, нове квалитетне иницијативе“. Зора Крстоношић се осврнула на тада актуелну реформу високог образовања, закључујући како „Филозофски факултет у том правцу стварно није пошао путем како треба да иде један факултет друштвених наука“. Навела је да је један од идејних проблема и однос наставника према обавезама на факултету: „Ми имамо ову појаву да на пример професори факултета много путују по иностранству“. Упозорила је да иако се захтеви за боравак у иностранству правдају стручним уздизањем, „иза свих тих тежњи се крије интерес и материјални и други, и ако се узме било који извештај са факултета, па када се погледа колико су било који од тих професора из наше средине провели у редовној настави, а колико је провео у иностранству, онда су то страшне диспропорције, онда 
се види да је један професор у току школске године, која траје десет месеци био само на испитима било почетним или завршним, а да је читаво то време за њега то радио неко други, поред свих својих редовних обавеза““. ${ }^{10}$

На седници Секретаријата ПК 29. марта 1963. године прва тачка дневног реда била је посвећена кадровима и настави у области друштвених наука на Универзитету у Новом Саду. У вези с тим, уводно излагање имала је Десанка Ромић, која је истакла како је „потреба да се разговара о друштвеним наукама на Универзитету у Новом Саду проистекла из раста самог Универзитета, јер је достигнут један ниво, који захтева нешто другачију бригу и однос убудуће“. Анализирајући стање на Филозофском и Правном факултету у Новом Саду, односно Економском у Суботици, закључила је да је најважнија „изградња даље физиономије и структуре наставних група, то јест, катедара, као и појединих дисциплина“. Апострофирајући Филозофски факултет, приметила је да су основне контуре група (тада их је било 8, са 40 дисциплина) „грубо утврђене, од стране друштвених фактора, али је још доста нерешеног у пропорцијама дисциплина, у захтевима да се постигне одређени оријентир код студената“. ${ }^{11}$

Као пример да се оставља превише места „личним концептима наставног особља“ навела је Катедру за југословенску књижевност, на којој су наводно биле запостављене македонска и словеначка књижевност, ,а до недавно те две књижевности нису улазиле ни у дипломски испит. Називи, а поготову садржина, као такви, сами за себе говоре о недостајању правог концепта катедре у целини и појединостима, јер да тога има вероватно не би дисциплина носила назив: Приморске и покрајинске књижевности и слично“. Приметила је и да приступ у анализама књижевних појава при реализацији наставе има печат идејних ставова наставника, тако да се и на тој линији јављају позитивистичка, феноменолошка и слична гледања, вулгаризација, политикантство у науци, најчешће без покушаја креативне марксистичке анализе токова и утицаја. Предаје се теорија књижевности, у коју се доста упрошћено уносе елементи марксистичке естетике, без познавања естетике, у њеном филозофском значењу“.

Као посебно забрињавајућу појаву навела је чињеницу да се избегава обрада најновије, послератне књижевности „која је богата и за студенте и омладину најзанимљивије поглавље наше књижевности“. Учење страних књижевности базирало се на страним уџбеницима, заснованим на „импресионизму и позитивизму“. Такође, замерила је да се сувише форсира књижевност, науштрб учења и знања језика. На рачун катедре за југословенске језике изнела је запажање да се она додуше „афирмисала на теорији структурализма у земљи и напољу, али међу научницима, у земљи је мало који упућен да процени шта она значи“. С друге стране, катедра за мађарски језик је похваљена за марксистички прилаз материји књижевности и језика, „у чему има заслуга шеф Катедре“. Група за историју је, поред похвале за успех у организовању наставе и покушаја да се „колико-толико прилагоди општим настојањима за једном научнијом и идејном интерпретацијом, да

\footnotetext{
${ }^{10} \mathrm{AB}$, Фонд 334, Записник са проширене седнице Секретаријата ПК СКС за Војводину од 16. 6. 1961.

${ }^{11}$ АВ, Фонд 334, Записник са седнице Секретаријата ПК СКС за Војводину од 29. 3. 1963.
} 
се рационалније постави“, оптужена за следеће слабости:

- Недостатак захвата у појаве XX века

- Оптерећеност периферним питањима, фактима и интерпретацијама без довољног ослона на историјске и материјалне услове развоја нашег друштва и света, онако како то претпоставља марксизам.

- Недовољно развијање струке у смислу да она буде постављена југословенски, рационално и сл. Један призвук на ту тему је и однос група унутар факултета и једна потреба интегрирања са другим факултетима, како са становишта нашег идејног јединства, тако и са становишта штедње, ефикасности, и слично (рецимо: какав је контакт и каква су гледања и односи група: југословенска и мађарска књижевност, затим да ли су нам потребне групе за француски и немачки, са ким сарађујемо у односу на друге факултете и слично).

- Питање наставе Основа науке о друштву, коју органи факултета и не решавају и слично.

- Питање личног става наставника, према друштвено-политичкој стварности Југославије и схватање своје обавезе у формирању одређеног лика интелектуалца ангажованог за социјализам.

- Одвојеност од школског живота Покрајине и учауреност у такозвани академски ред, иако много пута тај ред и није“.

После свега, Зора Крстоношић је за пропусте на Филозофском факултету олакшавајућу околност нашла у кадровским тешкоћама „у којима је изостао наш организован утицај, а о чему је било много говора и приговора. Добрим делом због тога што су чланови СКЈ у стручном погледу најчешће у незавидном положају, њихов утицај на најсуштинскија питања наставе је омануо и ишло се пречесто на уступке и неангажовање“. Позвала је на активније учешће комуниста у животу и раду Факултета, али и упозорила на потребу „подизања кадрова, у чему смо такође доста пропустили“. На крају је навела да је за ПК „од интереса и то да факултетско особље има већ своје место у структури друштва у Новом Саду“. У дискусији која је уследила, незадовољство стањем на Филозофском факултету испољио је Тодор Јовановић („На Филозофском факултету је један део људи, који свесно не усвајају марксизам, зато што су формирани на другим основама и не желе да уступају другачијим идејним основама“), док је Ђурица Јојкић стао у заштиту наставног особља група за енглески, француски и немачки поводом приговора да су њихови студенти „под утицајем Запада“.

Матица српска је поново помињана на седници Секретаријата ПК 28. априла 1966. године, поводом актуелних међунационалних односа. Мирко Чанадановић је афирмативно говорио о раду Матице српске на културном и просветном плану, набрајајући иницијативе „од ширег југословенског значаја почевши од правописа и Новосадског договора 1954. године, преко акција које тамо воде на изради биобиблиографског лексикона, историје књижевности народа Југославије, до терминолошких речника словеначког, македонског и српско- 
хрватског језика. У Матици српској се сада покреће и Зборник за славистику, који треба да буде југословенски са југословенском редакцијом. Матица издаје и зборник за ликовне уметности, јединствену југословенску публикацију такве врсте, а 'Стеријино позорје' издаје часопис и сређује документацију о позоришној уметности у читавој нашој земљи, итд. Ту је и издавање 'Српске књижевности у сто књига', рад на Речнику савременог српско-хрватског књижевног језика и др.“12

Помињући и активности других установа културе у Новом Саду, Чанадановић је изнео свој утисак да је толики број активности општејугословенског значаја нашао своје место у центру Војводине „због извесних компромисних схватања, да је ово можда мало тзв. натурални терен. То се у јавности не говори тако често, али се може ту и тамо осетити. Примера ради, истичем полемику око језичких питања. Очигледно је успостављена једна релација Загреб - Нови Сад, којом је Београд сасвим заобиђен, па су и неки људи из Загреба, који су овде код нас недавно бивали, истицали значај ове релације Нови Сад - Загреб, почев од првог гостовања СНП у Загребу у прошлом веку, па до Правописа итд“. Похвално је говорио и о богатој сарадњи „коју има Матица српска са Матицом хрватском и са одговарајућим академијама, што је дало читав низ заиста крупних резултата“.

С друге стране, Миладин Гвозденов је приметио како су „извесне наше институције“ склоне ,да пруже шансу и љубазно гостопримство, чак врсту 'азила' извесним појединцима и групама из Загреба, Словеније и другде, који су тамо доживели одређени фијаско (и у политичком погледу) који и даље претендују на извесне 'авангардне' тенденције у културном, филозофском и теоретском животу“. У том контексту је, поред Трибине младих и часописа Поља и њиховим везама са појединцима из загребачког Праксиса и словеначке Перспективе, поменуо и Матицу српску: „Поменуо бих онај пример са једне од прошлих скупштина, када је чика Божа Ковачевић искористио прилику да поздрављајући скупштину Матице српске у име САН 'превали' преко говорнице као омакло му се да каже како је 'пре неколико био тамо у Бановини Хрватској'. Вероватно да он то на неком другом месту не би смео, али чини му се ваљда у таквом амбијенту може. Такође, помало је чудно да је на последњој седници био и делегат Српског културног друштва из Загреба. Нећу рећи да му нема места као декану на скупштини Матице српске али мислим да таква делегирања и таква окупљања нису баш неопходна... Такође, мислим да ће бити бар непријатно данас-сутра, када се отвори антикварница у здању Матице српске са искључивим написима ћирилицом; што у моменту отворених расправа о језику може да се узме као својеврсна искључивост и доведе у сумњу искреност признавања оба писма латинице и ћирилице“.

\footnotetext{
${ }^{12} \mathrm{AB}$, Фонд 334, Записник са седнице Секретаријата ПК СКС за Војводину од 28. 4. 1966.
} 


\section{Извори и литература:}

\section{Извори:}

Архив Војводине, Нови Сад, Фонд 334 (Покрајински комитет).

\section{Литература:}

Бјелица, Слободан, Студентски протест на Новосадском универзитету јуна 1968. године, Истраживања, 23, Нови Сад 2012.

Дошлић, Ненад, Матииа српска 1941-1951, Нови Сад 2011.

Милисавац, Живан, Матииа српска 1826-1964, Нови Сад 1965.

Шимуновић Бешлин, Биљана, Матица српска у Краљевини Југославији, Београд 1997. 


\title{
A CONTRIBUTION TO THE STUDY OF HISTORY OF MATICA SRPSKA AND THE FACULTY OF PHILOSOPHY IN NOVI SAD
}

\begin{abstract}
Summary
As an institution with the longest tradition on the territory of the Autonomous Province of Vojvodina, Matica Srpska was in the focus of interest of the party's leadership in Vojvodina, that is, the Provincial Committee. Members of PC criticised the management of Matica because of their mass conception of work and national colouredness. They recommended to Matica to turn to a more scientific and cultural activity; there was a special evaluation of the work of the Science Department of Matica Srpska, which was reproached for national exclusiveness and for neglecting the history of the labour movement; the roots of those oversights in Matica's work were above all found in the inseparability of Matica as a cultural institution and its publishing company; Matica was also blamed for the appearance of isolationism among the minorities in Vojvodina. It was also accused of national-Romantic views and thus having created a refuge for ideologists of Great Serbia, and other dissident groups from all over Yugoslavia. The Faculty of Philosophy was first mentioned in the meetings of the PC a year before its establishment. In the following fifteen years the work of this school of higher education in Novi Sad was carefully monitored by the supreme political organ of the communists of Vojvodina. Criticism was usually connected to the lack of Marxist approach in the study of social sciences, and this chronic problem was not solved until the end of the 1960s, despite the constant efforts to rejuvenate the teaching staff and their ideological upbringing. Apart from their ideological weaknesses, the teachers of the Faculty of Philosophy were criticised for other oversights, and sometimes the PC analysed the work of the entire departments (for Serbo-Croatian Language and Yugoslav Literature, History, Hungarian Language, English Language, German Language, etc.).
\end{abstract}

Philosophy.

Keywords: Matica Srpska, Novi Sad, Provincial Committee, Faculty of 